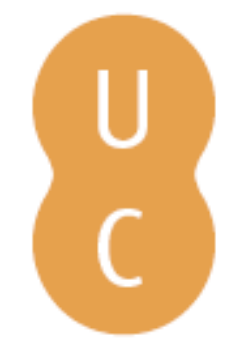

\title{
pommalina
}

Se toda a argumentação é retórica, então toda a retórica deve ser oratória: Chaïm Perelman versus Olivier Reboul

\author{
Autor(es): $\quad$ Vicente, Joaquim Neves \\ Publicado por: Imprensa da Universidade de Coimbra \\ URL \\ persistente: URI:http://hdl.handle.net/10316.2/32025 \\ DOI: $\quad$ DOI:http://dx.doi.org/10.14195/978-989-26-0498-5_16 \\ Accessed : $\quad$ 26-Apr-2023 14:51:11
}

A navegação consulta e descarregamento dos títulos inseridos nas Bibliotecas Digitais UC Digitalis, UC Pombalina e UC Impactum, pressupõem a aceitação plena e sem reservas dos Termos e Condições de Uso destas Bibliotecas Digitais, disponíveis em https://digitalis.uc.pt/pt-pt/termos.

Conforme exposto nos referidos Termos e Condições de Uso, o descarregamento de títulos de acesso restrito requer uma licença válida de autorização devendo o utilizador aceder ao(s) documento(s) a partir de um endereço de IP da instituição detentora da supramencionada licença.

Ao utilizador é apenas permitido o descarregamento para uso pessoal, pelo que o emprego do(s) título(s) descarregado(s) para outro fim, designadamente comercial, carece de autorização do respetivo autor ou editor da obra.

Na medida em que todas as obras da UC Digitalis se encontram protegidas pelo Código do Direito de Autor e Direitos Conexos e demais legislação aplicável, toda a cópia, parcial ou total, deste documento, nos casos em que é legalmente admitida, deverá conter ou fazer-se acompanhar por este aviso.

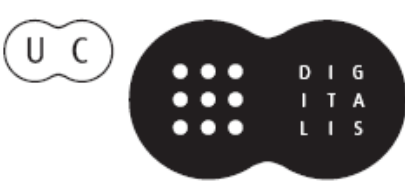




\title{
RHETORIC AND ARGUMENTATION IN THE BEGINNING OF THE XXIst CENTURY
}

\author{
EDITED BY
}

Henrique Jales Ribeiro
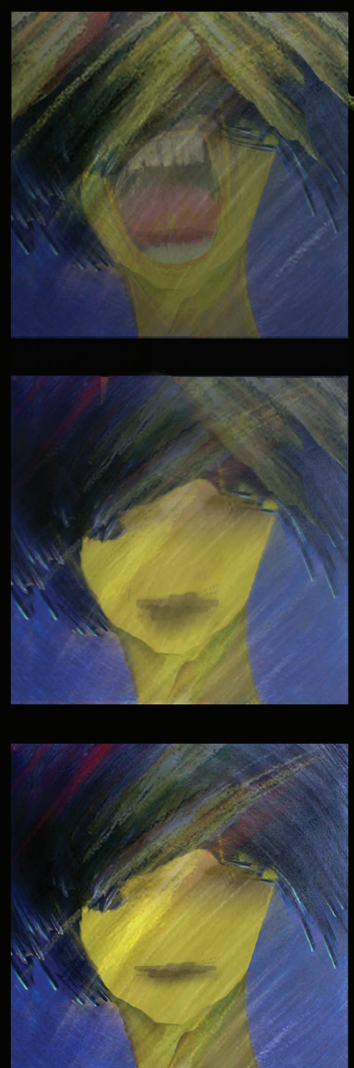
(Página deixada propositadamente em branco) 


\title{
RHETORIC AND ARGUMENTATION IN THE BEGINNING OF THE XXIst CENTURY
}

\author{
EDITED BY
}

Henrique Jales Ribeiro

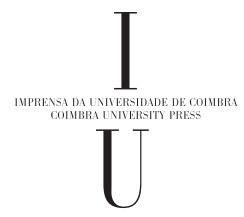

- COImbra 2009 
COORDENAÇÁO EDITORIAL

Imprensa da Universidade de Coimbra

Email: imprensauc@ci.uc.pt

URL: http://www.uc.pt/imprensa_uc

Vendas online: http://siglv.uc.pt/imprensa/

CONCEPÇÃO GRÁFICA

António Barros

CAPA

José Luís Madeira (IA / FLUC)

PRÉ-IMPRESSÁO

Paulo Oliveira

[PMP]

EXECUÇĂO GRÁFICA

Sereer, Soluçóes Editoriais

ISBN

978-989-8074-77-5

Depósito LEGAL

???????????????????????

OBRA PUBLICADA COM A COLABORAÇĀO DE:

\title{
FCT Fundação para a Ciência e a Tecnologia
}

MINISTÉRIO DA CIÊNCIA, TECNOLOGIA E ENSINO SUPERIOR Portugal

\author{
s \\ Ciência.Inovaçã̃o Programa Operacional Ciência e Inovação 2010 \\ 2010 MINISTÉRIO DA CIÊNCIA, TECNOLOGIA E ENSINO SUPERIOR \\ Unidade I\&D | Linguagem, Interpretação E Filosofia \\ ๑ JULHO 2009, IMPRENSA DA UNIVERSIDADE DE COIMBRA
}




\title{
CHAPTER I 6
}

\section{SE TODA A ARGUMENTAÇĀO É RETÓRICA, ENTÃO TODA A RETÓRICA DEVE SER ORATÓRIA: CHAÏM PERELMAN VERSUS OLIVIER REBOUL}

\author{
Joaquim Neves Vicente*
}

RESUMO: Partindo da legitimidade da distinção entre demonstração e argumentação (Perelman), assumindo também o vínculo inextricável entre argumentação retórica e persuasão, a nossa intervençáo parte da seguinte questáo: o que é que faz de um discurso um discurso retórico e, enquanto retórico, um discurso persuasivo? A tese que pretendemos defender, seguindo de perto a posição de Olivier Reboul, é a de que é retórico num discurso o que o torna persuasivo pela união do fundo e da forma: a) entendendo por fundo o conteúdo informativo e a estrutura lógica da argumentaçáo (lógos); b) entendendo por forma o que diz respeito à afectividade (o éthos e o páthos), à construção (dispositio) e ao estilo (elocutio), dando a este último ênfase particular. Dito de outro modo, o discurso retórico, porque se quer persuasivo, tem de assentar sempre em dois pilares: o pilar argumentativo e o pilar oratório. - É por causa do pilar oratório que a retórica se torna mais suspeita, mas é também por ele que a retórica se torna, para o bem e para o mal, mais eficaz, tornando difícil a paráfrase da mensagem e a réplica. Para contrabalançar os desequilíbrios de um discurso persuasivo, a situação retórica clássica sempre postulou o direito ao contraditório, a outro(s) discurso(s) e instituiu dois princípios ou critérios: o princípio da transparência (sabe-se que o orador ou advogado está a defender a sua tese ou causa e tem a obrigação de lhes dar todas as oportunidades); e o princípio da reciprocidade (sabe-se que outro orador ou advogado irá fazer o contraditório).

\footnotetext{
* Universidade de Coimbra, Faculdade de Letras, Instituto de Estudos Filosóficos, 3004-530 Coimbra, Portugal.

Grupo de Investigação "Ensino de Lógica e Argumentação” (LIF/FCT).

E-mail: jnevesvicente@net.sapo.pt
} 


\section{INTRODUÇÃO}

Partindo da legitimidade da distinção entre demonstração e argumentação, tão cara a C. Perelman, assumindo também o vínculo inextricável entre argumentação retórica e persuasão, a nossa intervenção parte da seguinte questão: - O que é que faz de um discurso um discurso retórico e, enquanto retórico, um discurso persuasivo?

A tese que pretendemos defender, seguindo de perto a posição de Olivier Reboul, para quem a retórica é a arte de persuadir pelo discurso, é a seguinte: - É retórico num discurso o que o torna persuasivo pela uniáo do fundo e da forma: a) entendendo por fundo o conteúdo informativo e a estrutura lógica da argumentação (lógos); b) entendendo por forma o que diz respeito à afectividade (ao éthos e ao páthos), à construção (dispositio) e ao estilo (elocutio), dando a este último ênfase particular. Dito de outro modo, o discurso retórico, porque se quer persuasivo e para ser persuasivo, tem de assentar sempre em dois pilares: o pilar argumentativo e o pilar oratório.

É por causa do pilar oratório que a retórica se torna mais suspeita, mas é também por ele que a retórica se torna, para o bem e para o mal, mais eficaz, designadamente, por tudo fazer para tornar difícil a paráfrase da mensagem e por tudo fazer para blindar a possibilidade da réplica.

Para contrabalançar os desequilíbrios, os perigos e os abusos de um discurso assim, persuasivo e potencialmente manipulador, a situação retórica clássica sempre postulou o direito ao contraditório, a outro(s) discurso(s) e instituiu dois princípios ou critérios reguladores: o princípio da transparência (sabe-se que o orador ou advogado está a defender a sua tese ou causa e tem a obrigação de lhes dar todas as oportunidades); e o princípio da reciprocidade (sabe-se que outro orador ou advogado irá fazer o contraditório).

Este é o sumário da intervenção que passamos de imediato a desenvolver. Começaremos com uma figura retórica designada tautologia. A retórica é a retórica. Com esta afirmação, queremos dizer que a retórica, pelo menos na sua versão clássica, é uma das duas grandes vias de procura do verosímil e do justo, a par do diálogo argumentativo ou dialéctica (à maneira socrática), sem com esta se confundir. A situação retórica não era uma situação de diálogo e de colaboração, mas de confronto efectivo e de polémica. O orador ou advogado A não tinha por objectivo persuadir ou convencer o orador ou advogado B ou chegar com ele a um consenso. A situação retórica era triádica e não diádica. Era a um terceiro - juíz(es) ou assembleia - que cada uma das partes se dirigia e a esse, e só a esse, terceiro é que era relevante persuadir.

São duas, de facto, as grandes maneiras de argumentar legadas pela tradição: - uma consistia em propor uma tese ou hipótese sem a impor, deixando a porta aberta às possíveis objecçóes e à possibilidade de outras proposiçóes ou teses ; - outra consistia em argumentar sem conceder, evitando tanto quanto fosse possível a possibilidade da réplica.

Sobre a questão de saber como procurar a verdade, são, de resto, bem conhecidas as passagens da República, $348 a-b$, e do Êtifron, 7 b-d. Sabe-se, pelo passo do Êtifron, que Platão admite, quando o desacordo não incide sobre aquelas matérias em que é possível a adopção dos procedimentos objectivados de medir, contar ou pesar, a alternativa entre a) o método dialéctico, por perguntas e respostas, e $b$ ) o método do "debate" oratório que, à maneira dos dissói logói de Protágoras, colocava, frente a frente, dois discursos antagónicos, um pró e outro contra. 
Também se sabe, pelo citado passo da República, que a preferência de Platão ia para o método dialéctico, por, entre outras razóes, evitar o recurso aos juízes e conceder aos parceiros de diálogo o duplo papel de causídicos e juízes. Mas também se sabe que outro era o caminho escolhido pela retórica.

\section{REBOUL E AS NOVAS RETÓRICAS}

Para uma melhor aproximação à tese que aqui sustentamos, servir-nos-emos do confronto com as posiçóes com as quais Reboul mais se confrontou e mais confrontou a sua definição de retórica.

No Colóquio "Argumentation et Signification" que decorreu, em 1987, no Centre International de Cerisy-la-Salle, organizado pelo Centre Européen pour l'Étude de l'Argumentation, com a intenção expressa de colocar frente a frente as várias perspectivas contemporâneas sobre retórica e argumentação, cujos textos foram editados por Alain Lempereur (Lempereur 1987), no volume L'Argumentation, Reboul toma posição relativamente a quatro dos mais importantes modos de entender a retórica na actualidade. A intervenção de Reboul tem por título a sugestiva pergunta "Pode haver uma argumentação que não seja retórica?” (Reboul 1987: 107).

Consideremos as quatro posiçóes, uma a uma, tendo por base a questão já enunciada: o que é que faz de um discurso um discurso retórico e, enquanto retórico, um discurso persuasivo?

Para um primeiro grupo de investigadores, todos eles teóricos da literatura, com destaque para o Groupe $\mu$ (Groupe $\mu$ 1970) da Universidade de Liège, é retórico tudo o que num discurso é literário, ou seja, tudo o que constitui um corte ou desvio (écart) com o grau zero do discurso ou com a prosa não literária. São as figuras de estilo que assumem aqui o lugar da diferença entre retórico e não retórico. Esta "nova retórica", uma "retórica do estilo" ou "retórica das figuras" tem o mérito, diz Reboul, de estabelecer o vínculo inegável entre retórica e literatura ou entre retórica e poética, mas tem também o demérito de omitir o mais importante: o vínculo entre retórica e persuasão. Reduzir a retórica à literatura, mais exactamente à estilística, como se o discurso retórico representasse apenas um desvio ou corte (écart), através das figuras, com um suposto grau zero da literatura, é pouco, demasiadamente pouco. O que é visado num discurso é muito mais do que a intenção estética. É a intenção de dar a ver mais e melhor e de uma outra maneira, que dá credibilidade às figuras. A tese do écart, se dá conta da figura (quod est disputandum), não dá de todo conta da retórica, nem mesmo do estilo, pois há estilo sem figuras e figuras sem estilo. De resto, a figura não adquire sentido a não ser inserida no discurso. Na retórica, em que as figuras estão codificadas, a percepção da figura como um écart equivaleria à perda imediata (ipso facto) do seu efeito persuasivo. A regra da retórica é a de dissimular a sua própria retórica. O estilo, mais do que pelo desvio, define-se, diz Reboul (1984: 103), pelas escolhas: escolha das palavras que além de justas hão-de soar bem, escolha das figuras que além de ornamentos hão-de ser argumentos, escolha dos ritmos que além de estéticos hão-de ficar no ouvido, escolha das construçôes que além de elegantes hão-de ser surpreendentes.

Para Jean-Blaise Grize, a segunda posição com a qual Reboul quer confrontar a sua definição, é retórico “ce qui appartient à l'orateur (...) et cherche à aider à 
la réception de ce qui est présenté" (citado por Reboul 1987: 108). O retórico diz respeito, neste caso, ao que no discurso facilita a sua recepção, a sua compreensão, a sua comunicaçáo. O mérito reside neste caso no reconhecimento da importância do carácter pedagógico de qualquer discurso que se quer fazer compreender; o demérito reside na subvalorização do carácter argumentativo.

Posição bem distinta é a de C. Perelman que, com inteira clareza, identifica retórica e argumentação. As figuras de estilo, que para o Groupe $\mu$ constituem a diferença específica do retórico, são em Perelman assumidas como um caso particular de argumentação (Perelman 1976: 226). A metáfora é encarada como um raciocínio por analogia condensado; até a ironia é reduzida a um argumento. Fecunda, esta outra "nova retórica", uma "retórica (só) da argumentação", designada também "retórica dos conflitos", também ela é redutora por negligenciar um aspecto relevante que Reboul não hesita em designar por "charme": a emoção ou o rir que provoca a retórica e que tanto contribui para o seu poder persuasivo, ainda que por isso a tornem suspeita. Em Introduction à la rhétorique, Reboul manifesta todo o seu apreço pelo trabalho de C. Perelman e da sua colaboradora L. Olbrechts-Tyteca, consubstanciado no Traité de l'argumentation, la nouvelle rhétorique, do qual diz (Reboul 1991: 97):

Esta obra, que se inscreve na tradição retórica de Aristóteles, de Isócrates e de Quintiliano, é realmente a teoria do discurso persuasivo. Os seus autores partiram de um problema, não linguístico ou literário, mas genuinamente filosófico: como fundamentar os juízos de valor? O que é que nos permite afirmar que isto é justo, ou que aquilo não é belo? Procuraram numa lógica do valor, paralela à da ciência, e acabaram por encontrá-la na antiga retórica, completada como justeza pela dialéctica. A grande descoberta do TA [Tratado da Argumentação] é que, entre a demonstração científica e a arbitrariedade das crenças, existe uma lógica do verosímil, que nomeiam como argumentação e que unem à antiga retórica.

Um elogio tão expressivo é, no entanto, mitigado de imediato por uma forte crítica (Reboul 1991: 98):

Ela [a obra de Perelman] é, no entanto, também incompleta. Com efeito, se o TA descreve maravilhosamente as estratégias da argumentação, ignora os aspectos afectivos da Retórica, o delectare e o movere, o charme e a emoção, essenciais à persuasão.

A quarta posição que Reboul selecciona, no Colloque de Cerisy-la-Salle de 1987, para esclarecer a sua noção de retórica, é representada por Francis Jacques que situa a retórica no degrau inferior de uma escala que, quanto ao rigor e à verdade, começa na demonstração, prolonga-se na argumentação e tem o seu nível mais baixo na retórica. Para o autor de Dialogiques, como para Platão, a retórica comporta sempre uma parte de rotina e de lisonja (flatterie) que a tornam suspeita. Caracteriza-a também a unilateralidade e o desejo de vencer, que faz do orador o senhor dos outros e do seu poder um poder de domínio. Só a argumentação "dialógica" é verdadeira. Retórica e argumentação distinguem-se porque se opóem no seu projecto: a retórica pretende dominar, a argumentação (dialógica) pretende encontrar em comum. "Cette définition, 
je ne la partage pas, mais elle a du moins le grand mérite de poser le problème" (Reboul 1987: 109) - um “problema”, acrescentamos nós, que será um verdadeiro quebracabeças para Reboul, como o comprovam várias passagens das suas obras.

Neste conflito de definições, tendo de tomar posição (il faut trancher, diz Reboul), o professor vindo de Estrasburgo pronuncia-se nos seguintes termos (Reboul 1987: 109):

Tentarei fazê-lo, inspirando-me em Aristóteles, ou seja, na tradição. Como definir a palavra "retórico" como adjectivo? Que queremos dizer quando falamos de um discurso retórico, ou do aspecto retórico de um discurso? O que é "o retórico"? Eis a minha resposta: é retórico num discurso o que o torna persuasivo pela união do fundo e da forma. Entendo por fundo o conteúdo informativo e a estrutura lógica do discurso. Por forma, tudo o que respeita à afectividade (ao éthos e ao páthos), à construção (dispositio), ao estilo e por último à dicção.

\section{O PILAR ARGUMENTATIVO E O PILAR RETÓRICO}

Como Reboul repetirá vezes sem conta, o que é retórico para ser persuasivo implica sempre dois pilares: um pilar argumentativo e um pilar oratório.

A essência da retórica, diz Reboul (1984: 32), não está no estilo nem na argumentação, mas na região da sua intersecção. Releva da retórica todo o discurso que funde argumentação e estilo, em que as três funçóes de instruir, agradar e comover estão presentes conjuntivamente e cada uma delas em colaboração com cada uma das demais, ou seja, releva da retórica todo o discurso que persuade pelo prazer e pela emoção, sustentado obviamente pela argumentação.

A primeira e mais importante função da retórica é persuadir. O problema maior será o de saber por que meios um discurso é persuasivo. De entre esses meios, uns são mais racionais, outros mais afectivos (Reboul 1984: 7; sobretudo 1991:7). O persuasivo ou o retórico, porque se dirige ao homem na sua totalidade, terá de comportar meios racionais e meios afectivos. Dos meios racionais fazem parte os argumentos (lógos), cujas modalidades maiores são os entimemas (que substituem o raciocínio silogístico da lógica) e em particular os exemplos (que substituem a indução); dos meios afectivos, destacam-se o éthos, ou seja, o carácter que deve assumir o orador para captar a atenção e ganhar a confiança do auditório e o páthos, isto é, as tendências, os desejos, as emoções do auditório. Aos meios mais racionais chama Reboul (1991: 7-8) o lado mais argumentativo da retórica, aos meios mais afectivos chama ele o lado mais oratório.

Num discurso propriamente retórico, isto é, que visa persuadir, as figuras só raramente são um ornamento gratuito. A unidade da retórica reside na fusão. Nunca um discurso retórico é simplesmente estético ou simplesmente argumentativo. Fora do seu contexto argumentativo, as figuras não passam de "flores ressequidas num ervanário", como diz Perelman; reduzidas a figuras de estilo deixam de ser figuras retóricas.

Certa recuperação contemporânea da retórica como retórica das figuras não faz, por isso, justiça à verdadeira retórica, à retórica antiga, à retórica de Aristóteles, onde as figuras ocupam, de resto, um lugar modesto. 
A figura, termo latino que traduziu o termo grego skhêma, pertence à linguagem desportiva (movimento típico do desportista ou da dançarina). Como no desporto ou na dança, também na retórica as figuras são ao mesmo tempo livres e codificadas. Sem código seriam ininteligíveis, sem liberdade não passariam de factos vulgares da língua e não do estilo. A asa do avião já não é figura mas simples catacrese, de uso forçado, por não dispormos de designação alternativa. Outro tanto se passa com a perna da mesa ou o braço da cadeira. As figuras, necessariamente requeridas pela estética literária (sobretudo na poesia), ao serem mobilizadas também na retórica tornam-se nesta, além de estéticas, persuasivas. A prova mais recente da fusão estético-persuasiva é a publicidade, onde assistimos ao uso massivo de metáforas, hipérboles, antíteses... para além da rima, também esta importante do ponto de vista persuasivo, por facilitar a recordaçáo e gerar um sentimento de evidência.

Os gestos do orador, o tom e as inflexóes da voz são puramente oratórios. Mas, sê-lo-ão as figuras de estilo? Uma metáfora, uma hipérbole, uma antítese, sem deixarem de ser oratórios e como tal contribuírem decididamente para agradar e provocar emoção, são também argumentativos, enquanto argumentos condensados, capazes de maior contundência (plus frappant).

Como separar oratório e argumentativo em expressóes célebres como "A religião é o ópio do povo", de Karl Marx, para justificar a sua crítica à religião ou a expressão "homo hominis lupus est", de Hobbes, para justificar a sua teoria política. Nestes dois casos, cada um dos enunciados é, ao mesmo tempo, tese e argumento ou, se se preferir, conclusão e premissa. A religião é o ópio do povo, porque a religião é um ópio. $\mathrm{O}$ homem é lobo do homem, porque o homem é lobo.

Quem pode ignorar, para dar um outro excelente exemplo, o efeito poderoso, de dois em um, da curtíssima expressão "cortina de ferro", lançada por Churchill, em 1946, quando disse que "uma cortina de ferro tinha caído sobre a Europa"? Como se cortina náo fosse já um grande mal, ainda por cima ela era de ferro.

Ao iniciar o capítulo II da sua La Rhétorique, a primeira afirmação que nele lemos é mesmo esta: "C'est la figure que montre le mieux le joint, propre à la rhétorique, entre le style et l'argumentation" (Reboul 1984: 35). Em "La figure et l'argument" (Reboul 1989: 10), diz o professor que, mesmo num texto literário e poético, as figuras não são gratuitas. A metáfora, por exemplo, aparece como um "raccourci d'argument par analogie”. A derivação - figura que consiste em usar na mesma frase duas ou mais palavras com o mesmo étimo - é de grande efeito persuasivo, como se pode observar nestes dois exemplos. No slogan de Vichy "A França aos Franceses" se substituído por "A França aos cidadãos" todo o efeito persuasivo desapareceria. De igual modo a exortação de De Gaulle à luta com "É tempo de os trabalhadores trabalharem" foi muito mais persuasiva do que se se limitasse a dizer, por exemplo, "É necessário que os operários trabalhem". Num caso como noutro, a derivação sugere um vínculo lógico entre a essência e a sua manifestação: França para os Franceses e trabalho para os trabalhadores.

Nestes como em muitos outros exemplos a eficácia persuasiva reside no carácter condensado do discurso. É melhor dizer muito com poucas palavras do que dizer pouco com muitas. Os melhores enunciados são sempre os mais curtos. O problema maior destes enunciados, como também das tautologias ("um homem é um homem", "uma mulher é uma mulher", "um cêntimo é um cêntimo”, "cognac é cognac”) é que são demasiado curtos para o muito que querem dizer, ficando abertos a todas as 
interpretações, com o mérito e o demérito de cada um os interpretar segundo as suas preferências. É bem possível que todos estejam aparentemente de acordo, quando todos estão realmente em desacordo.

Passemos agora das palavras-embuste e das expressôes contundentes a construçôes um pouco mais elaboradas. Vejamos dois exemplos de realização discursiva que consideramos muito bem sucedidos do ponto de vista argumentativo e do ponto de vista oratório, por explorarem com eficácia bastante dois argumentos a que Perelman chamaria argumentos quase-lógicos.

Exemplo 1. Jean Piaget na sua obstinada oposição ao ensino transmissivo e na sua porfiada defesa do cognitivismo soube cunhar neste enunciado conciso, eficaz e persuasivo o seu ponto de vista. "Chaque fois qu'on explique quelque chose à l'enfant, on l'empêche de l'inventer." "Cada vez que se explica alguma coisa a uma criança, impede-se que ela a invente." Ou, numa outra versão: "Chaque fois qu'on enseigne quelque chose à l'enfant, on l'empêche de l'apprendre." "Cada vez que se ensina alguma coisa a uma criança, impede-se que ela a aprenda."

Concorde-se ou não com a afirmação, reconhecer-se-á que ela é um belo achado. Reconhecer-se-á que se trata de uma enunciação feliz, facilmente repetível, com as vantagens de ser difícil a réplica e fácil a conservação na memória.

Tentarei responder a este primeiro exemplo de forma retórica ${ }^{1}$ e de dois modos distintos, ambos oratórios. Eis a primeira tentativa de resposta retórica, com recurso à contraposição e a alguma ironia:

"Sempre que ensinamos alguma coisa a um aluno, retiramos-lhe a possibilidade de ser ele a aprendê-la." Bela tirada oratória [efectivamente proferida numa conferência do autor], paralisante do prazer de ensinar, mesmo por parte daqueles que efectivamente são mestres. Assim se ensina que não é preciso ensinar, assim se defende, em suma, que o professor deve ensinar menos para que o aluno aprenda mais por si próprio.

Eis a segunda tentativa de resposta retórica, com réplica pelo recurso ao argumento a contrario, acrescentando-lhe um argumento adicional.

Sempre que não explicamos qualquer coisa de importante a uma criança corremos o risco de ela jamais a encontrar ou jamais a aprender, com a desvantagem acrescida de vermos a pobre criança perdida no atoleiro dos ensaios inúteis e dos erros paralisantes.

Exemplo 2. Nos anos 60, a administração americana pôs a correr esta outra fórmula também lapidar, depreciativa para o trabalho dos professores, certamente polémica,

\footnotetext{
${ }^{1}$ Entendo por de forma retórica aquela forma de argumentar que tem lugar na situação retórica, no tribunal ou na assembleia, com o tempo limitado, como diz Platão no Teeteto, pela clepsidra, onde não seria eficaz a forma científica própria do ensino. Parto da afirmação do próprio Aristóteles (Retórica, 1355 a) segundo o qual "O discurso científico é próprio do ensino, e o ensino é aqui impossível, visto ser necessário que as provas por persuasão e os raciocínios se formem de argumentos comuns, como já tivemos ocasiāo de dizer nos Tópicos, a propósito da comunicação com as multidôes.”
} 
mas nem por isso menos convincente, dotada que é de grande efeito persuasivo para o senso comum: "There can be no Teaching without Learning"/Não há ensino se ninguém aprende nada (cf. Israel Scheffler 1960: 42 e ss.). Certamente, sem terem tido conhecimento da fórmula, também há alguns anos foi escrito aqui nos muros da FLUC: "Aqui ensina-se, mas não se aprende." A força persuasiva do argumento reside justamente na sua aparência demonstrativa, mais exactamente na aparência de uma contradição evidente, cujo implícito é o carácter correlativo dos termos ensinar e aprender.

Tentarei responder a este segundo exemplo já não de forma retórica mas antes de forma pedagógica. ${ }^{2}$ Se estivesse a analisar o enunciado com os meus alunos diria algo assim:

O slogan é falacioso por dissimular que entre ensinar e aprender a distância pode ser abissal e por tomar como correlativos dois termos que são apenas relativos. Há muitas matérias que são objecto de ensino que não chegam a ser aprendidas, como há muitas outras que são aprendidas sem terem sido ensinadas. $\mathrm{O}$ enunciado não passa de um truísmo, se se toma o verbo ensinar como verbo de resultado. Tomado como verbo de resultado, é evidente que não se ensinou se alguém não aprendeu. Mas ensinar, antes de ser um verbo de resultado, é um verbo de acção intencional. Do slogan se podem fazer pelo menos duas interpretaçóes concorrentes. Lançado pelas administraçóes escolares contra os professores, ele aponta o dedo acusador: "Se os vossos alunos não aprendem nada é porque vocês não sabem ensinar nada." Mas poderá o professor fazer aprender só por si? O único desafio pedagógico sério que o "lema" pode comportar é o de insistir na necessidade de prestar atenção não apenas aos conteúdos de ensino como fim em si, mas também aos alunos, às suas dificuldades e às condiçôes do aprender. É neste sentido, se adoptarmos uma interpretação caridosa, que se poder ler este outro slogan também dos anos sessenta: "We teach children, not subjects"/"Nós ensinamos crianças, não matérias".

Para este terceiro slogan, poder-se-ia, ao invés, procurar uma réplica retórica do género:

Resta saber se se ensina alguém, quando não se lhe ensina nada.

Os discursos pedagógicos de que retirámos estes exemplos são, de facto, um domínio fértil para a exploração do carácter retórico da linguagem da educação, onde constatamos a escolha criteriosa de palavras "politicamente correctas" e "pedagogicamente convenientes", como "autonomia" (das escolas ou da universidade), "retenção" dos alunos, para evitar falar em reprovação, até ao propalar de slogans como "aprender a aprender" ou "aprender a pensar", "democratizar o ensino" ou "descolonizar a criança”. Quem é que náo deseja a autonomia? Quem é que não tem por má a reprovação? Quem tem a coragem de negar que o que importa é "aprender a aprender" ou "aprender a

2 Entendo por de forma pedagógica aquela forma de argumentar que tem lugar no ensino, sem limite de tempo, onde se procede a uma avaliação crítica dos argumentos do ponto de vista formal e informal. 
pensar"? São estas palavras-armadilha e estes slogans-engodo que tornam a contestação mais difícil e a réplica mais longínqua. Qual é o pai ou qual é a mãe que contesta a fórmula mais recente do Ministério da Educação que promete "uma escola a tempo inteiro"?

Tentando de novo responder a este outro exemplo de forma retórica, diria, replicando:

Resta saber se uma escola a tempo inteiro não é uma escola a tempo perdido. Se todo o tempo é tempo de escola, onde está o tempo de vida? A completa escolarização da existência das nossas crianças não acarretará a deserção simétrica da família e da comunidade por parte dos nossos alunos? Pobre sociedade esta que só tem a escola para realizar toda a educação! É porque a sociedade já deixou, toda ela, de ser educativa?

Se o discurso pedagógico é notoriamente retórico, o discurso político não o é menos. Consideremos alguns exemplos.

Exemplo 1. Um ditador instalado no poder, confrontado com uma manifestação de opositores na rua dirá, recorrendo a um cliché (o cliché é a arma do poder, só o slogan é que é a arma da oposição), que os manifestantes não passam de um "punhado de agitadores", ou seja, que são poucos e ainda por cima desordeiros. Talvez fosse uma boa réplica responder-lhe que não são um "punhado" mas antes uma "mão bem cheia", não de "agitadores" mas de "corajosos".

Exemplo 2. Foi aqui em Coimbra, numa festa dos estudantes, mais precisamente numa festa da Latada, que se pôde ler num cartaz este argumento de efeito persuasivo fácil, pelo menos para públicos menos esclarecidos. "Se o socialismo fosse bom, o capitalismo já o tinha comprado". Embora o argumento seja frouxo, a formulaçáo linguística, convenhamos, é excelente, tornando difícil, também aqui, a formulação de uma réplica à altura da provocaçáo. A excelência retórica e oratória do enunciado reside num óptimo uso do raciocínio entimemático tão característico do discurso retórico. Poderíamos reconstruir o argumento que está por detrás do enunciado com este silogismo: O capitalismo compra tudo o que é bom (premissa maior); Ora, o capitalismo não compra o socialismo (premissa menor); Logo, o socialismo não é bom (Conclusão). Reduzindo o argumento a uma forma canónica, dir-se-ia: 1) Tudo o que é bom é comprado pelo capitalismo (premissa maior). 2) O socialismo náo é comprado pelo capitalismo (premissa menor). 3) O socialismo não é bom (Conclusão). Bem se vê a diferença entre a formulação completa do argumento com três enunciados, o que faria dela uma formulação pesada e a formulação reduzida a um único enunciado, que a torna leve. Mais relevante do ponto de vista retórico é a hábil ocultação do princípio geral, ou seja, da premissa maior, que, posta "para debaixo da mesa", passa despercebida, sem ter de se assumir o ónus da prova que neste caso não seria tarefa fácil. A "arte" da formulação está na dissimulação do que constitui os pés de barro do argumento. A formulação tem ainda a vantagem de deixar ao leitor do cartaz a tarefa, esta fácil, de retirar a conclusão óbvia.

Neste como em muitos outros casos observa-se o que Reboul $(1975,1991)$ chama de "retórica do atalho" (rhétorique du raccourci). Um argumento é atalhado sempre que não é explicitada uma das premissas e/ou a conclusão. E a regra é, por um lado, 
a de evitar a formulação das premissas menos evidentes ou mais difíceis de provar, e, por outro, a de procurar a formulação das premissas, e só das premissas, que inclinam o leitor ou ouvinte para a conclusão desejada.

O que é mais frequente no discurso retórico, quando recorre aos entimemas, é a formulação apenas de uma das premissas e da conclusão. Em determinados contextos, o atalho pode ir até mais longe, bastando formular apenas a premissa maior, sem formulação da conclusão. Noutros contextos, basta também formular apenas a premissa menor. Numa discussão sobre a infalibilidade pontifícia alguém poderá apenas dizer: O Papa é um homem. Ao dizê-lo nesse contexto, o argumento fica completo porque facilmente se subentende Todos os homens são faliveis (premissa maior) e O Papa é falivel (conclusão).

Casos há também em que apenas é enunciada a conclusão. O médico que, numa consulta de rotina, após medir a febre de um cliente, lhe diz: "Você está doente", limita-se a enunciar a conclusão de um raciocínio que poderíamos formular assim: 1) "A febre é sinal de doença" (premissa maior); 2) "Você tem febre" (premissa menor); 3) "Você está doente" (conclusão).

Exemplo 3. Nem os nossos melhores políticos escapam ao uso da retórica, nem sempre da mais séria. Relatou o Dr. Almeida Santos no encerramento do Congresso A Retórica Greco-Latina e a sua Perenidade, que decorreu aqui em Coimbra, de 11 a 14 de Março de 1997, organizado pelo Instituto de Estudos Clássicos, estes dois casos de intervenção parlamentar.

Evocarei a propósito dois momentos parlamentares em que eu próprio - que nisso sou vezeiro - fiz apelo à "santa ironia", como lhe chamava o Eça.

Era eu Ministro dos Assuntos Parlamentares e fui à Assembleia defender uma proposta de lei do Governo, de que eu próprio tinha sido co-autor. Regulava ela o sistema remuneratório dos titulares dos cargos políticos. Gizámos o sistema em pirâmide descendente, por percentagens decrescentes da remuneração do Presidente da República. A proposta veio a ser aprovada, e ainda hoje vigora. Mas a bancada do Partido Comunista zurziu-a impiedosamente, como fonte de injustificadas mordomias. Quando me coube a vez do repique lembrei-me de me sair com esta:

- Bramam os senhores porquê? Apesar de eu, como autor da honrosa malfeitoria, ter fixado no montante que fixei o meu próprio vencimento, sabem os senhores quanto passo a ganhar a mais? Quatro mil escudos! O preço de um charuto do vosso camarada Fidel Castro!

— Dos menos caros! — disse alguém do hemiciclo.

O efeito deste 'fait divers' foi surpreendente !

Noutra oportunidade fui, na mesma qualidade [de Ministro dos Assuntos Parlamentares], defender a única proposta de lei que, desde há décadas, consagrou uma modesta correcção das rendas de prédios urbanos até então congeladas. Também estive na origem dessa proposta "celerada".

Assim a considerou, com larga cópia de razôes na defesa dos inquilinos, uma vez mais a bancada comunista. Quando me coube responder ironizei assim:

- Pelo que vejo os senhores recusam-se a compreender que, quando tiverem conseguido eliminar o último senhorio, terão liquidado o último inquilino. Sem 
casas para arrendar, nem dinheiro para as construir, o único recurso é o regresso à copa das árvores, com o pequeno incómodo de, a quem nos procura, deixarmos de dizer 'entre', passando a dizer 'suba'!

Exemplo 4. Não resistimos a introduzir também duas imagens de uma campanha eleitoral francesa, mais exactamente das Presidenciais de 1986.

Compare-se para uma análise retórica das imagens:

a) os elementos que singularizam o éthos de cada um dos cartazes,

b) os elementos que diferenciam o páthos de cada um dos cartazes,

c) e, por fim, a rima, que constitui um elemento também ele relevante da réplica.

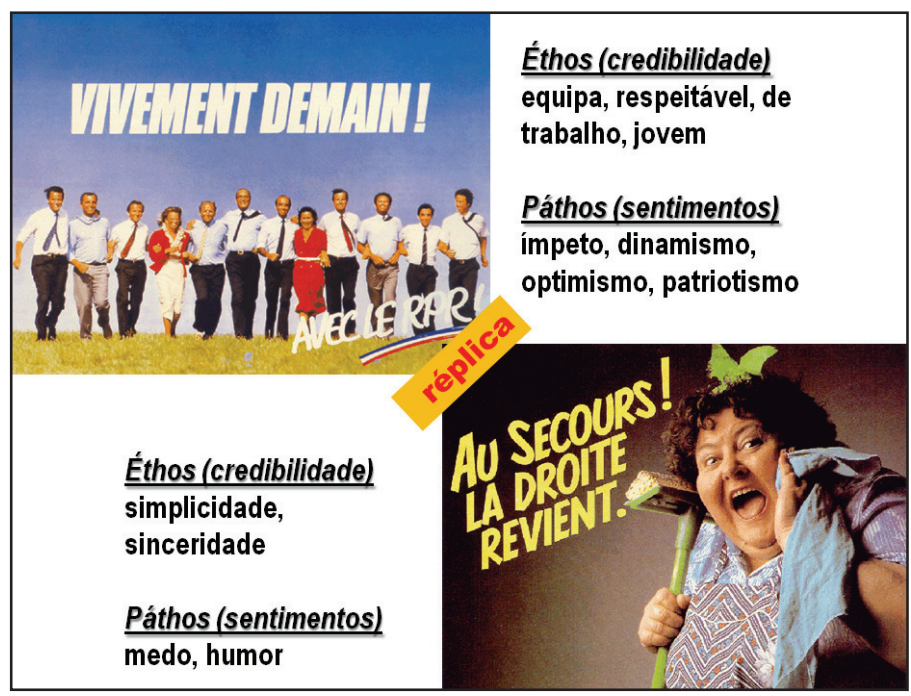

\section{A IMPOSSIBILIDADE DE PARAFRASEAR A MENSAGEM E O SEU FECHAMENTO}

Servem os exemplos dados atrás, e inclusive estas imagens, para sublinhar uma vez mais que a argumentação retórica, na retórica clássica, tal como hoje, era e é bem pouco dialógica. Cada advogado, cada parlamentar, tinha e ainda tem a incumbência de: à sua causa, dar todas as oportunidades de vencer; e, à causa contrária, levantar todos os obstáculos.

Servem estes mesmos exemplos para introduzir duas outras características apontadas por Reboul (1989: 109), no referido Colóquio de Cerisy-la-Sale, como específicas do discurso retórico.

Acrescento que se pode reconhecer a presença do retórico por estes dois sinais: a impossibilidade de parafrasear a mensagem e o seu fechamento.

Nada há mais demolidor no debate retórico (judiciário, parlamentar ou mesmo publicitário) que a sobreposição da excelência da réplica à fragilidade ou mediocridade do argumento inicial. 
Daremos quatro exemplos:

Exemplo 1. Tudo corria bem na publicidade do jornal L'Euvre (A Obra), potenciada com o slogan "Les imbéciles ne lisent pas L'Euvre" (Os imbecis não lêem A Obra), até que um detractor se lembrou da seguinte réplica: "Ils l'écrivent" (Escrevem-na).

Exemplo 2. No seu desejo de afirmação industrial frente ao Ontário, o Québec lançou este belo slogan: "Québec sait faire?" O slogan não resistiu mais, quando um maledicente do Ontário se lembrou apenas de perguntar: "Sait faire quoi?".

Exemplo 3. Um slogan como "O tabaco mata lentamente" é certamente um mau slogan porque não hão-de faltar fumadores a retorquir "Ainda bem! Eu não tenho pressa nenhuma em morrer". Melhor fora que o slogan dissesse apenas "O tabaco mata".

Exemplo 4. Reconhecer-se-á que foi brilhante a réplica de R. Aron à tese de Karl Marx, segundo a qual "A religiáo é o ópio do povo", quando $\mathrm{R}$. Aron retorquiu que, em alternativa, o marxismo se transformou no "ópio dos intelectuais". Referimo-nos à obra do autor L'Opium des intellectuels, de 1955.

A retórica não se reduz, obviamente, a enunciados curtos e lapidares como aquelas que acabamos de registar, mas também é verdade que não dispensa formulaçôes linguísticas que estão próximas dos slogans, das máximas, dos provérbios ou das crias, como pontos de ancoragem do discurso. Tais formulaçóes podem agradar pelo que defendem, apregoam ou prometem, mas agradam também, e muitas vezes sobretudo, por elas mesmas, pela sua graça verbal, pela excelência estética da sua formulação, porque fazem rir, porque são cómicas ou porque embaraçam. A excelência de certas formulações reside precisamente no seu carácter gostoso.

O tirano Sereníssimo, recorda Reboul (1975: 63), espantado com a semelhança que um estrangeiro tinha com ele, perguntou-lhe: - A tua mãe habitou aqui no palácio? Respondeu o estrangeiro: - Não foi a minha mãe, mas sim o meu pai. Insultado grosseiramente pelo tirano, o pobre estrangeiro poderia ser tentado a retorquir: - Tué que és bastardo! Mas não o fez. E assim, diante do poder sem graça afirmou-se a graça sem poder. E foi a graça e não o poder que levou a melhor.

Nem os filósofos escaparam à tentação gostosa da fórmula lapidar e à eficácia sintética e persuasiva da fórmula contundente. "Tudo o que é real é racional e tudo o que é racional é real", resumiu Hegel, em Principios da Filosofia do Direito. T. Hobbes no Leviathan, cap. 17, rematou: "Convençóes sem espadas, não passam de palavras ("Covenants, without the swords, are but words"). J. Bentham erigiu como máxima "A maior felicidade para o maior número". Kant proclamou, na Critica da Razão Pura, que "pensamentos sem conteúdos são vazios, intuiçóes sem conceitos são cegas".

Dito o que acaba de ser dito, consideremos as objecçóes que o uso e sobretudo o abuso do pilar oratório enfrenta. É sempre possível que a arte de dizer bem se desobrigue de dizer a verdade. É muito provável que caia na tentação de, dispondo do poder da palavra, queira também dispor da fraqueza dos homens. Com frequência deslizou ela de uma arte de persuadir para uma arte de enganar e de uma arte de agradar para uma arte de corromper.

E Reboul não alivia em nada as objecções, quando acrescentou, como vimos, que são constitutivas do discurso retórico: a impossibilidade de parafrasear a mensagem e o seu fechamento. É a partir da situaçáo retórica, e só desta, que se têm de ler e porventura legitimar as duas marcas com que Reboul nos surpreende. 


\section{O PILAR ORATÓRIO E OS PRINCÍPIOS RETÓRICOS}

O exemplo privilegiado por Reboul (1991: 111) para servir de paradigma à impossibilidade de parafrasear uma mensagem e dar conta do seu fechamento é a célebre abertura da intervenção de Cícero (Catilinam, I, 1) junto do Senado romano: Quo usque tandem abutere, Catilina, patientia nostra? É difícil reunir tanta retórica numa só frase. Sem quaisquer considerandos prévios, ex abrupto, e não perdido no meio do discurso, o desafio náo deixa margem à réplica, com a vantagem de aparentemente se dirigir a um outro (Catilina), quando, na realidade, se quer dirigir e quer envolver o Senado porque, diz, a patienta é nostra. Mesmo que Catilina respondesse que parava de imediato as hostilidades, não respondia à objecção que a frase acusatória contém, a saber, que já houve muita paciência, que houve abuso, que a paciência é questão nossa. Numa mesma frase, duas figuras fundidas, ainda que de sentido contrário: a apóstrofe (fingir dirigir-se a outrem) e a prosopopeia (fingindo num só acto locutório fazer falar pela sua voz um orador fictício, o Senado, ao referir nostra).

Fechado e sem permitir a réplica, o discurso retórico parece dar razão aos que, como Francis Jacques, falam de não diálogo e de unidireccionalidade comunicativa. Não deve por isso a argumentação desfazer-se da retórica? Mas será que pode? Quem é que não vê que, sem esta retórica, sem um tal modo de dizer, fechado e não parafraseável, Cícero teria fracassado junto do Senado? A causa justa náo corre o risco de passar despercebida se não for defendida por fórmulas contundentes? A argumentação de Cícero foi eficaz. Tê-lo-ia sido de outro modo? Ao proceder como procedeu, Cícero foi desonesto? A retórica é necessariamente ilegítima?

Reboul (1991: 111-112) responde deste modo:

Do nosso ponto de vista, o que é próprio de uma boa argumentação não é suprimir o aspecto retórico - uma argumentação cinzenta não é forçosamente mais honesta - mas equilibrá-lo de acordo com dois critérios. À não paráfrase, pode-se opor o critério da transparência: que o ouvinte esteja tanto quanto possível consciente dos meios pelos quais se altera a sua crença; o charme e a poesia do discurso náo são destruídos por isso, mas são dominados. Ao fechamento, pode-se opor o critério da reciprocidade: que a relação entre o orador e o auditório não seja assimétrica, que o auditório tenha direito de resposta. Estes dois critérios não tornam a argumentação menos retórica, tornam-na mais honesta.

Esta dupla exigência de Reboul [transparência e reciprocidade] merece um destaque particular, por se tratar da resposta mais importante do autor às objecçóes da não paráfrase e do fechamento; em suma, por se tratar da melhor defesa e da melhor legitimação do uso da retórica. Um discurso retórico não será manipulador, se, e só se, ocorrerem, conjuntamente, as duas condiçóes.

O recurso à retórica, isto é, a meios oratórios é, de resto, indispensável em vários domínios. É indispensável no tribunal; é indispensável nas assembleias; é-o também no ensino.

Comecemos pelo ensino. Pior do que um professor retórico é certamente um professor morno que provoca tédio e aborrecimento nos seus alunos. Para instruir torna-se indispensável muitas vezes acrescentar às razóes (ao lógos) o éthos e o páthos. 
Uma comunicação eficaz não se compadece com uma linearidade discursiva, com uma linguagem châ, com um ponto zero da simples formulação sintáctica correcta dos enunciados. Ao conhecimento rigoroso da matéria e a uma correcta realização discursiva (o lógos), o professor náo pode evitar o recurso a uma boa realização retórica, isto é, ao éthos e ao páthos. Não é por causa dela que o professor é menos honesto ou é manipulador. Um ensino sem retórica não será, por isso, mais verdadeiro; e um ensino com retórica não será, por isso, menos verdadeiro. Retórica e honestidade não são necessariamente incompatíveis; retórica e verdade também não. Resta saber se ensino honesto e ensino da verdade podem ter sucesso sem retórica. Pode o ensino libertar-se da retórica? O ensino é, até, pensa Reboul, a circunstância, por excelência, em que o uso da retórica pode ser mais pacífico. Com uma condição: que sejam assegurados os dois critérios que, sem tornarem a argumentação menos retórica, a tornam mais honesta, única forma de evitar a manipulação que, no caso do ensino, toma o nome de doutrinação: o critério da transparência e o critério da reciprocidade, isto é, a) que os alunos saibam que o professor usa da retórica para os persuadir, convencer ou tornar compreensível uma informação, uma teoria, uma interpretação; b) que o professor ensine também a retórica, que o professor proporcione aos seus alunos conhecimentos que lhes permitam perceber o que há de retórico no discurso pelo qual o professor ensina.

Distinta é a situação do tribunal. E aqui não se aplicam do mesmo modo os critérios de transparência e reciprocidade. Pretender aplicar aos debates judiciais o modelo pedagógico seria pretender que, no final, o culpado confessasse livremente o seu crime e que ele mesmo solicitasse a pena. A nossa sociedade e a nossa democracia não o exigem. No domínio judicial, o diálogo irenaico (irénique) cede lugar ao debate polémico. É público e, portanto, transparente, que cada um dos advogados procura dar à sua causa todas as oportunidades. Não se trata de persuadir ou convencer um adversário, mas um terceiro, isto é, o tribunal a quem cabe decidir. Aqui, um advogado não está só. A reciprocidade é garantida porque todo o advogado tem diante de si um outro, capaz de detectar a sua retórica e de a contrariar por uma outra.

Algo de semelhante se passa no debate político e nas assembleias, pelo menos em democracia. É público e transparente que cada deputado ou partido toma partido. O sistema democrático garante, por outro lado, o princípio da reciprocidade, porque admite vários partidos. Também aqui não se trata de convencer o partido adversário mas um outro "tribunal", o do povo ou da assembleia.

Duas conclusôes se podem retirar da situação retórica do tribunal e da assembleia que tornam legítima a retórica: a primeira é que o perigo de manipulaçáo diminui, quando um advogado ou orador náo está só, quando a sua retórica tem de enfrentar uma outra retórica; a segunda, o verdadeiro objectivo da retórica, nas relaçóes sociais, não é de julgar, mas de preparar o julgamento que um terceiro, juiz ou povo, tem obrigação de fazer. Nestes domínios, a relação argumentativa não é unilateral, nem bilateral, mas triangular.

Uma outra situação é a da filosofia. O propósito do filósofo é distinto do do advogado. $\mathrm{O}$ que ele se propóe não é defender uma causa mas uma tese. Uma tese não tem incidências directas nas decisóes práticas, nem implica necessariamente pôr fim a um debate ou estabelecer um veredicto. De resto, uma tese não se impóe, apenas se propóe. E o filósofo propóe-na antes de mais a si mesmo, o que não anula nem a 
controvérsia, nem a retórica, porque no interior de si mesmo, ele sustenta os prós e os contras, sendo, ao mesmo tempo, o orador e o seu adversário, cabendo ao seu público ouvinte ou leitor o papel do tribunal.

Ensino, debates judiciais, debates políticos e filosofia, eis as situações argumentativas mais típicas em que a retórica, inevitável e indispensável, pode escapar à crítica da manipulação e legitimar-se meritoriamente.

Outra e distinta é a situação da propaganda e da publicidade: unilateral e assimétrica; onde as duas marcas específicas do discurso retórico, a saber, a impossibilidade de parafrasear a mensagem e o seu fechamento, não são equilibradas pelos dois critérios reguladores, ou seja, os princípios da transparência e da reciprocidade.

Observe-se, a título de exemplo, a imagem da publicidade Moulinex. Os produtos Moulinex libertam a mulher ou aprisionam-na ainda mais ao seu estatuto tradicional de género? Grande falácia!

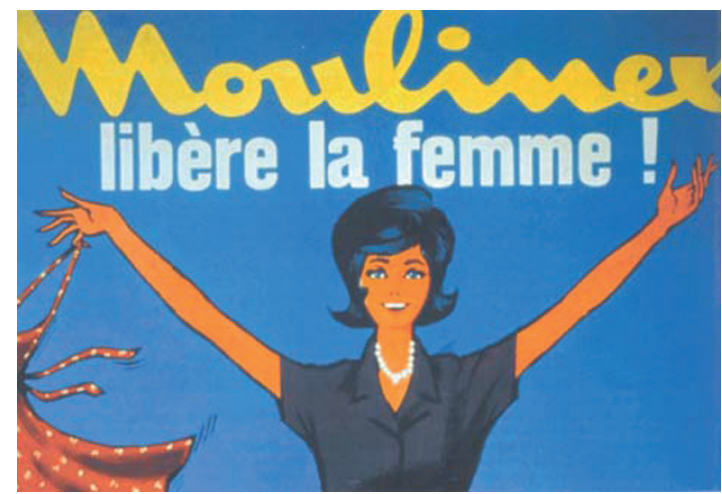

\section{ALGUMAS ALEGAÇÓES FINAIS}

Terminamos a nossa intervenção com algumas breves alegações finais contra cinco das maiores objecçóes contra a retórica.

1. Acomodaçáo a uma filosofia relativista. Acusa-se a retórica de se ter acomodado e acomodar a uma filosofia relativista, se não mesmo niilista. Mas isso não quer dizer que a implique. No domínio das relaçôes humanas não há evidências, a não ser negativas, mas há causas que podem ser mais ou menos verosímeis. Há mesmo causas consideradas objectivamente justas: a de Sócrates, a de Joana d'Arc, a de Dreyfus, etc., ... para nós, hoje, mas não para os contemporâneos dessas causas. A justiça nessas causas só é possível vê-la por intermédio dos advogados. A pior injustiça é crer que a justiça é evidente. Não é ; ela carece de muita retórica e de todo o empenho possível.

2. Fusão do afectivo e do racional. Acusa-se a retórica de ter misturado e misturar de forma inextricável o afectivo e o racional. Mais uma vez não é a retórica que o determina, é o homem que o exige, porque é ele mesmo uma mistura inextricável de afectividade e racionalidade. Os sentimentos não se equivalem: podem ser cegos ou esclarecidos, versáteis ou profundos, infantis ou adultos. O valor de uma retórica afere-se pela qualidade dos sentimentos que mobiliza, mas essa decisão já não é de ordem técnica, mas ética. 
3. Retórica e sinceridade. A retórica seria a denegação da expressão sincera. $\mathrm{O}$ problema é que há uma sinceridade aparente e uma sinceridade real; e esta também carece de retórica. A sinceridade só por si não preserva ninguém da inabilidade, da imperícia, da incoerência, da obscuridade. Não é porque (apenas) se é sincero, que em política se convencem os eleitores, em ensino se leva a aprender, em religião se fazem crentes. É preciso toda uma arte para se exprimir, uma arte sem a qual não seremos credíveis ou até não seremos pura e simplesmente compreendidos. Para ser sincero não basta querer exprimir o que se pensa ou sente; é preciso poder fazê-lo, saber fazê-lo, ser capaz de o fazer. E é aqui que se revela o verdadeiro problema (problema moral) de toda a retórica: que náo é o problema da mentira, mas o problema do poder que ela confere.

4. Polémica e não dialógica. Acusa-se a retórica de ser polémica e não dialógica. Não é a retórica que é polémica. A realidade é que o é e admite uma pluralidade de pontos de vista e, consequentemente, raciocínios a favor e contra. Uma causa é-o também. É por isso normal que mesmo a causa menos boa tenha os seus advogados, não porque seja justa, mas porque é justo que ela seja defendida. É este também o princípio da democracia. A polémica não é a guerra; é até a condição de a evitar porque nela o combate dá lugar ao debate e o arbitrário ao razoável. Enquanto falamos, não nos matamos. A retórica é a arte de persuadir pelo discurso, não pela força.

5. Manipulação. A vitória da retórica, diz-se, é alcançada à custa da manipulação. Os advogados têm a obrigação de tudo fazer pela sua causa. A resposta à objecção não pode ser senáo esta: é preciso conhecer as técnicas da manipulação para delas não ser vítima. Se a retórica como técnica pode subjugar, como teoria ela liberta.

E aqui abriria um novo capítulo: o da paideia retórica, que tanta falta nos faz hoje, porque ela ensinava mais do que a arte de manipular a arte de nos defendemos das manipulaçóes. Mas este seria o tema de uma outra e certamente mais longa intervenção. 


\section{REFERÊNCIAS}

DOURY, Marianne, et MOIRAND, Sophie (coord.) (2004), L'Argumentation aujourd'hui: positions théoriques en confrontation, Paris: Presses Sorbonne Nouvelle.

GRIZE, Jean-Blaise (1986), "Raisonner en parlant", in M. Meyer (éd.), De la métaphysique à la rhétorique, Bruxelles: Éditions de L'Université de Bruxelles.

GROUPE $\mu$ (1970), Rhétorique générale, Paris: Larousse.

JACQUES, Francis (1979), Dialogiques: recherches logiques sur le dialogue, Paris: PUF.

LEMPEREUR, Alain (éd.) (1987), L’Argumentation, Liège: Mardaga.

PERELMAN, Chaïm, et OLBTRECHTS-TYTECA, Lucie (1976), Traité de l'argumentation : la nouvelle rhétorique, Bruxelles: Éditions de L’Université de Bruxelles (3 ${ }^{\text {ème }}$ édition).

PLATÃO (1993), República, Lisboa: Fundação Calouste Gulbenkian. (2005), Teeteto, Lisboa: Fundação Calouste Gulbenkian.

REBOUL, Olivier (1975), Le Slogan, Bruxelles: Éditions Complexe. -(1984), La Rhétorique, Paris: PUF.

____(1987) "Peut-il y avoir une argumentation non rhétorique?", in Alain Lempereur (éd.), L'Argumentation, pp. 107-119.

____(1989), "La figure et l'argument", in O. Reboul et J.-F. Garcia, Rhétorique(s) (Cahiers du Séminaire de Philosophie, 9), Strasbourg, pp. 5-28.

-__-_(1991), Introduction à la rhétorique, Paris: PUF.

SCHEFFLER, Israel (1960), The Language of Education, Springfields: Ed. Ch. Thomas.

SANTOS, António de Almeida (2000), "O uso da retórica na vida política e parlamentar", in José Ribeiro Ferreira (coord.) (2000), A Retórica Greco-Latina e a sua Perenidade, Fundaçáo Eng. António de Almeida, 2. ${ }^{\circ}$ Vol., pp. 981-995. 

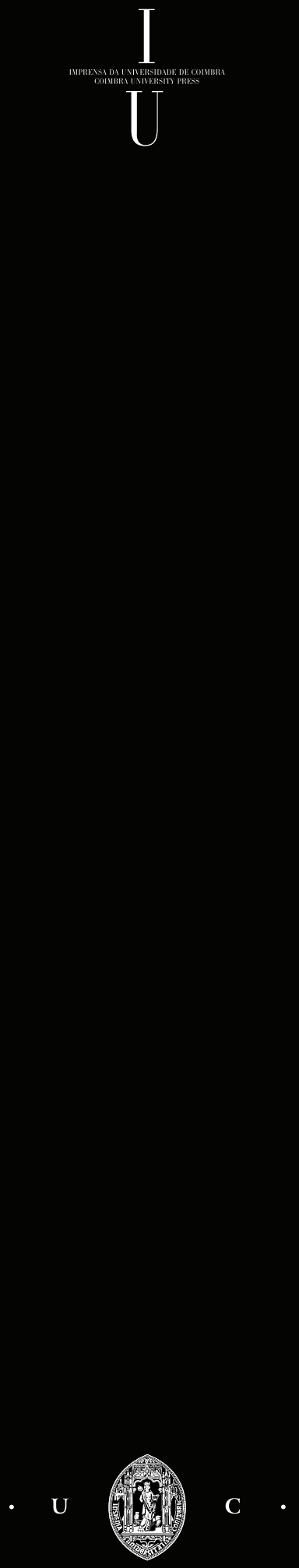